This item was submitted to Loughborough's Research Repository by the author.

Items in Figshare are protected by copyright, with all rights reserved, unless otherwise indicated.

\title{
Scale-down studies for assessing the impact of different stress parameters on growth and product quality during animal cell culture
}

PLEASE CITE THE PUBLISHED VERSION

http://dx.doi.org/10.1016/j.cherd.2013.04.002

\section{PUBLISHER}

Elsevier / @ The Institution of Chemical Engineers

VERSION

AM (Accepted Manuscript)

\section{LICENCE}

CC BY-NC-ND 4.0

\section{REPOSITORY RECORD}

Nienow, Alvin W., William H. Scott, Christopher J. Hewitt, Colin R. Thomas, Gareth Lewis, Ashraf Amanullah, Robert Kiss, and Steven J. Meier. 2014. "Scale-down Studies for Assessing the Impact of Different Stress Parameters on Growth and Product Quality During Animal Cell Culture”. figshare.

https://hdl.handle.net/2134/14846. 
This item was submitted to Loughborough's Institutional Repository (https://dspace.lboro.ac.uk/) by the author and is made available under the following Creative Commons Licence conditions.

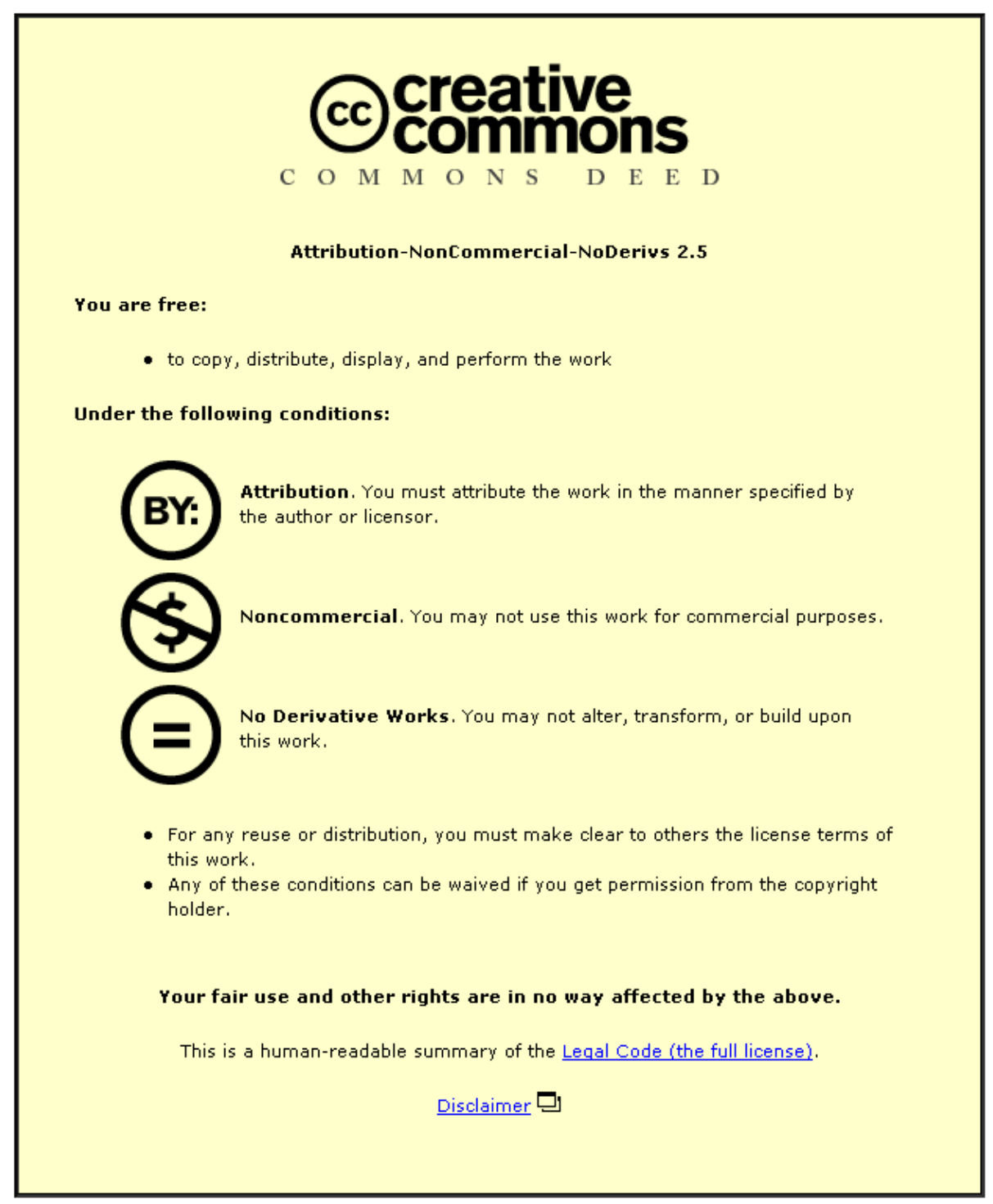

For the full text of this licence, please go to: http://creativecommons.org/licenses/by-nc-nd/2.5/ 


\title{
Scale-Down Studies for Assessing the Impact of Different Stress Parameters on Growth and Product Quality during Animal Cell Culture
}

\author{
Alvin W. Nienow ${ }^{\mathrm{a}, \mathrm{b}}$, William H. Scott ${ }^{\mathrm{a}, \mathrm{c}}$, Christopher J. Hewitt ${ }^{\mathrm{b}}$, Colin R. Thomas ${ }^{\mathrm{a}}$, \\ Gareth Lewis $^{\text {d }}$, Ashraf Amanullah ${ }^{\text {e,f }}$, Robert Kiss ${ }^{\mathrm{g}}$ and Steven J. Meier ${ }^{\mathrm{g}}$. \\ ${ }^{a}$ Centre for Bioprocess Engineering, University of Birmingham, B15 2TT, UK \\ ${ }^{b}$ Centre for Biological Engineering, Loughborough University, UK \\ ${ }^{c}$ now at Lonza Biologics plc, Slough, UK \\ ${ }^{d}$ MedImmune Cell Sciences, Milstein Building, Granta Park, Cambridge, UK. \\ ${ }^{e}$ Pharma Technical Development, Genentech, Inc., Oceanside, CA 92056, USA \\ ${ }^{f}$ now Biologics Development, Gilead Sciences, Oceanside, CA 92056, USA \\ ${ }^{g}$ Late Stage Cell Culture, Genentech, Inc., South San Francisco, CA 94080, USA
}

Corresponding author:

Alvin W. Nienow, Centre for Bioprocess Engineering, University of Birmingham, B15 2TT, UK: ph; 0121440 2344: E-mail; A.W.Nienow@bham.ac.uk 


\section{Abbreviations}

Ip Isoelectric point value

STR Stirred bioreactor

PFR Loop acting as an approximate plug flow reactor

FC Flow cytometer

HC Haemocytometer

VCN Viable cell number

DCN Dead cell number

sub Proprietary glucose feed as substrate 


\section{Bullet points}

- Repeatable fed batch cultivation of three different CHO cells is reported

- Recirculating $\mathrm{CHO}$ cells and media by peristaltic pump lowered process performance

- High laminar extensional energy dissipation rates did not lower process performance

- Neither did stirring with Rushton turbines at specific powers 50 times typical

- Protein quality was not affected under any of these operating conditions 


\begin{abstract}
.
Two series of reproducible fed-batch bench scale cultures have been undertaken, one series simulating the impact of spatial variations in $\mathrm{pH}$ and nutrients as found at commercial scale on performance, the other, the impact of fluid dynamic stresses associated with agitation. The first was unsuccessful because, somewhat surprisingly, the use of a peristaltic pump to circulate cells and medium through different spatial environments always led to a similar reduction in culture time and resulting product titre compared to uncirculated controls. This fall was sufficient to essentially mask other effects. In the second, even at maximum specific energy dissipation rates up to $\sim 160$ times $>$ with laminar extensional flow and $\sim 25$ times $>$ with turbulent flow compared to typical commercial conditions, no significant effects were observed on cell growth and viability. Most importantly, in all of the cases studied, product quality was unaffected compared to controls. In addition, it is suggested that because of the possibility of cell line specific behavior and the relationship between damage to entities and the Kolmogorov scale of turbulence, sensitivity to fluid dynamic stresses is best studied in turbulent bench scale bioreactors.
\end{abstract}

Keywords: $\mathrm{CHO}$ cells, mechanical stress, environmental stress, product quality, process performance. 


\section{INTRODUCTION}

Freely suspended animal cells have been grown commercially in agitated, stainless steel bioreactors since at least 1965 (Telling and Elsworth, 1965) when it was reported that one of $30 \mathrm{~L}$ was being used for the production of inactivated foot and mouth disease vaccine from BHK cells; and similar bioreactors were built at the $8 \mathrm{~m}^{3}$ scale at around the same time for the production of interferon from Namalwa cells (Pullen et al., 1985). More recently, bioreactors of $20 \mathrm{~m}^{3}$ or so have been installed at Lonza and Genentech (Nienow, 2006). In spite of these successes, since the beginning, there has been concern that because animal cells lack a cell wall, they were very prone to damage due to turbulent fluid dynamic stresses (often called shear 'sensitivity'), particularly due to impeller agitation and this concern was discussed in depth in a review (Nienow, 2006), In particular, it was shown that whilst the oxygen transfer requirements of the cells could be met by agitation intensities (expressed as mean specific energy dissipation rate, $\bar{\varepsilon}_{T} \mathrm{~W} / \mathrm{m}^{3}$ ) of the order 10 to $20 \mathrm{~W} / \mathrm{m}^{3}$ (the latter being used for comparison here), a wide variety of cells grew to the same cell density when subjected to $\bar{\varepsilon}_{T}$ values up to $250 \mathrm{~W} / \mathrm{m}^{3}$.

It was also shown that this perception of fragile cells had led to problems because the low agitation intensity could lead to poor spatial and temporal homogeneity. The latter was especially poor with respect to $\mathrm{pH}$ close to the surface of the medium where base for control was added (Langheinrich and Nienow, 1999) and an experimental scale-down model (Osman et al., 2002) indicated that this $\mathrm{pH}$ deviation could lead to a significant reduction in viable cell density when growing GS-NSO cells. Work with bacteria has also shown a poorer performance on scale-up due to inhomogeneities associated with nutrient addition in fedbatch fermentations and with $\mathrm{pH}$ control chemicals due to surface addition (Hewitt and Nienow, 2007). 
In spite of the earlier studies, the perception of cell fragility remains and recently, concern has been expressed that though cell viability may not be compromised at higher $\bar{\varepsilon}_{T}$ values, product quality, especially glycosolation, may be. To further explore such issues, Chalmers and co-workers (Godoy-Silva et al., 2009a, 2009b) have recirculated cells though a flow device in which cells are subjected to a converging, mainly extensional, flow at very high local laminar specific energy dissipation rates, $\varepsilon_{L} \mathrm{~W} / \mathrm{m}^{3}$. Their justification for the very high values utilized was that in a stirred bioreactor the maximum local turbulent specific energy dissipation rate, which is found very close to the impeller, is much greater than the average, i. e. $\left(\varepsilon_{T}\right)_{\max }>>\bar{\varepsilon}_{T}$. They assumed that $\left(\varepsilon_{T}\right)_{\max }=100 \bar{\varepsilon}_{T}$; and that, more importantly, high specific energy dissipation rates in turbulent and laminar flow should produce the same (or a similar) impact on cells during cell culture. Using $\varepsilon_{L}$ values of the order of $10^{6} \mathrm{~W} / \mathrm{m}^{3}$ with two different cell lines, they found a reduction in performance compared to that found at standard conditions $\left(\varepsilon_{T}\right)_{\max }$ around $2.5 \times 10^{4} \quad \mathrm{~W} / \mathrm{m}^{3}$ based on the assumption $\left.\left(\varepsilon_{T}\right)_{\max }=100 \bar{\varepsilon}_{T}\right)$. However, in the first case, cell growth was inferior compared to controls without recirculation (Godoy-Silva et al., 2009a); and in the second, it was product quality (Godoy-Silva et al., 2009b).

The work reported covers two projects with different objectives. However, they are brought together here because one of the findings in both studies was surprising; and at the same time, important for gaining further insight into the robustness of animal cells and their products under different processing conditions. One was undertaken at the University of Birmingham and aimed to investigate the impact of environmental stress on cells due to local high $\mathrm{pH}$ and glucose levels arising from surface feeding during large scale fed batch culture. In this study, a $\mathrm{CHO}$ cell line from MedImmune was used; and MedImmune also assessed the quality of the protein product. The technique used was based on one that had been used 
successfully when applied to microbial systems (Hewitt and Nienow, 2007). In this technique, first introduced by Enfors and co-workers (Larsson and Enfors; 1988), the medium and cells are circulated through a plug flow loop with a frequency similar to the average with which they circulate due to agitation at the large scale, The volume of the loop is chosen to match the size of the zone (relative to the total volume in the stirred bioreactor) where high concentrations of nutrients or $\mathrm{pH}$ control chemicals are found when feeding to the top surface of the large scale bioreactor, as is common practice.

The other study was undertaken later at Genentech using the laminar extensional flow device developed by Chalmers (Ma et al., 2002). The aim was to clarify the earlier work of Godoy-Silva et al. (2009a; 2009b) on the impact of laminar stresses on process performance and product quality using two Genentech production $\mathrm{CHO}$ cells lines. In addition, further studies with these two lines were conducted in a bioreactor agitated by dual Rushton turbines at turbulent mean specific energy rates, $\bar{\varepsilon}_{T}$ up to $1000 \mathrm{~W} / \mathrm{m}^{3}$. In studies, cell growth, product titre and antibody quality were all assessed.

\section{EXPERIMENTAL}

3L and 2L working volume, fed-batch, bench scale stirred bioreactors (STRs) were used to cultivate $\mathrm{CHO}$ cells producing an $\mathrm{IgG}$ antibody with $\mathrm{pH}$ and $\mathrm{dO}_{2}$ control; the first for the stresses associated with inhomogeneities due to glucose and $\mathrm{pH}$ and the second for the mechanical stress study respectively. Firstly, duplicate primary control runs were undertaken where cells were cultured in the bioreactor using standard conditions including low turbulent specific mean energy dissipation rates, $\left(\bar{\varepsilon}_{T}=\sim 20 \mathrm{~W} / \mathrm{m}^{3}\right)$. Secondly, duplicate runs were undertaken where each bioreactor was operated as in the primary control but cells and medium were taken from it and circulated through a loop, either by a peristaltic pump for both stress conditions; or by syringe pump for the mechanical stress study. In the secondary 
control runs for investigating the stress due to inhomogeneities due to nutrients or $\mathrm{pH}$, circulation was undertaken without any additions into the loop. Subsequently, for the actual investigation of homogeneities, duplicate runs were undertaken where additions were made into the loop (Fig. 1). For the secondary control for the mechanical stress study, the laminar extensional flow device was not included in the loop whilst for the actual investigation, it was. In both cases, circulation was only begun at day 4 to ensure that both cultures started in a similar fashion.

For the primary and secondary controls in the inhomogeneity study used a defined medium, including Pluronic F68 (Sigma-Aldrich, UK), with a temperature of $36.5{ }^{\circ} \mathrm{C}$, the $\mathrm{dO}_{2}$ being held at $30 \%$ using a fixed agitation speed and variable air flow rate. Sodium bicarbonate buffer ( $\mathrm{pH}$ 9.7) and sparged $\mathrm{CO}_{2}$ were introduced directly into the bioreactor on demand in order to control the $\mathrm{pH}$ in the bioreactor at 6.95. A proprietary glucose supplement ( $\mathrm{pH}$ 2.5) was also introduced into it using exponential feeding, starting when either the viable cell number $(\mathrm{VCN})$ had reached $1 \times 10^{6}$ cells $/ \mathrm{mL}$ (measured by haemocytometer and Trypan Blue exclusion and/or flow cytometric analysis using a Coulter Epics Elite Analyser (Beckman Coulter, UK)) or after day 4 from inoculation of the STR, whichever occurred first. In this way, the concentration of glucose in the bioreactor was maintained at $4.5 \mathrm{~g} / \mathrm{L} \pm$ $1.5 \mathrm{~g} / \mathrm{L}$. For the actual inhomogeneity studies, the aim was to maintain similar conditions in the bioreactor but either the sodium bicarbonate buffer or both it and the glucose supplement were introduced into the loop (PFR). The volume of the PFR (made of neoprene) mimicked the proportion of a commercial bioreactor $(\sim 5 \%)$ occupied by the feed plume as assessed by flow visualisation (Langheinrich and Nienow, 1999) and also used in earlier studies on the impact of feed zone inhomogeneities (Namdev and Thompson, 1992; Amanullah et al., 2001). Two rates of circulation through the loop were used, generated by a Watson Marlow $505 \mathrm{~S}$ peristaltic pump, to bracket the range of circulation times found at the low agitation 
intensities used at the $20 \mathrm{~m}^{3}$ scale to give mean residence times of $60 \mathrm{~s}$ (flow rate 150 $\mathrm{mL} / \mathrm{min}$ ) and $120 \mathrm{~s}$ (flow rate $75 \mathrm{~mL} / \mathrm{min}$ ) (Hewitt and Nienow, 2007). In addition, an experiment was undertaken in which the concentration of bicarbonate was increased a 100 fold to $2 \mathrm{M}$ to give $\mathrm{pH} 12.3$, as often very concentrated feeds are used in order to minimise storage volumes, excessive culture dilution and sterilisation costs. The duplicate runs undertaken are summarised in Table 1 based on the mean residence time in the loop and where the additions were made.

Three standard methods as employed by MedImmune were used to assess the effects of the various conditions imposed on the quality of the IgG protein: mass analysis using liquid phase chromatography (LC) followed by electrospray ionisation (ESI) coupled to a quadrapole time-of-flight (TOF) mass analyser, referred to as ESI-Q-TOF (Zhang et al., 2009); charge analysis using isoelectric focusing (IEF); glycoform profiling using normal phase high pressure liquid chromatography (NP-HPLC) using 2-aminobenzamide (2-AB) as the fluorescent tag, referred to as NP-HPLC 2-AB (Guile et al., 1996).

For the mechanical stress study, the cultures used a serum-free medium based on DMEM/F12 supplemented with $1 \mathrm{~g} / \mathrm{L}$ Pluronic F68, recombinant human insulin and hydrolyzed protein (peptone) with $\mathrm{dO}_{2}$ controlled at $30 \%$ and $\mathrm{pH}$ at 7.15 . The loop was essentially as described earlier (Godoy-Silva et al., 2009a; 2009b) with a $3.1 \mathrm{~mm}$ diameter Pharmed BPT tubing (Cole Parmer, Vernon Hills, IL) plus the extensional flow device with constrictions of $227 \mu \mathrm{m}$ and $762 \mu \mathrm{m}$ at a flow rate to give $\varepsilon_{L}$ values of $2.9 \times 10^{5} \mathrm{~W} / \mathrm{m}^{3}$ and $1.9 \times 10^{3} \mathrm{~W} / \mathrm{m}^{3}$ respectively. The two pumps utilized were a Cole Parmer peristaltic pump and a Pump 33, Harvard Apparatus dual syringe pump. In addition, a run was undertaken with one bioreactor as control and another one with dual Rushton turbines giving rise to a mean specific energy dissipation rates, $\bar{\varepsilon}_{T}$ after day 4 of either $360 \mathrm{~W} / \mathrm{m}^{3}$ or $1000 \mathrm{~W} / \mathrm{m}^{3}$. The antibody product quality was assessed using a Genentech protocol in a similar set of ways to 
that set out above. It should be noted that with the techniques employed to assess quality, it would be difficult to detect any changes in charge profiles associated with sialylation. However, since sialylation was not present in the antibodies produced from any of the cell lines used in this study, that limitation was not important.

Further details of the medium and the fed-batch and other operating conditions in the bioreactor are given elsewhere: for the $\mathrm{pH}$ and nutrient study (Scott, 2011) and mechanical stress study (Chaderjian et al., 2005).

\section{RESULTS AND DISCUSSION}

\subsection{Impact of stresses generated by $\mathrm{pH}$ and glucose excursions}

In the two primary control runs without circulation through the loop, the fed batch culture ran for 18 days producing an average maximum cell density of $\sim 8.5 \times 10^{6}$ cells $/ \mathrm{mL}$ (Fig. 2 and Table 2). Figure 3 shows the growth curves with cell viability, viable cell number and dead cells for all the runs conducted with the circulation loop in place. In Fig 3a to Fig $3 \mathrm{~d}$, in each case, the data obtained from the two runs with the loop in place but with addition of nutrients and $\mathrm{pH}$ control chemicals into the stirred bioreactor; are compared with that found with the duplicate runs related to one of the four scale down scenarios, simulating loss of homogeneity at the large scale.

A comparison of Fig 2 and 3 along with the data in Table 2 shows that though the maximum viable cell number varied from run to run, there was no consistent pattern with respect to the primary control, secondary control (with recirculation but with feed into the bioreactor) or the runs with feed into the loop. On the other hand, as can be seen, the maximum was reached earlier with the loop in place and that is also suggested by the higher growth rates $\left(\mu_{\max }\right)$ for these runs shown in Table 2 . In addition, for all runs with recirculation, at the end of the exponential phase, viability began to drop significantly $24 \mathrm{~h}$ after the maximum viable cell number was attained and they were all characterised by a 
shallow decline in cell viability from the end of exponential growth phase that contrasted with the primary control which exhibited an abrupt decline in cell viability only after a stationary phase with viability maintained above $90 \%$. As a result, the duration of all the cultures with recirculation was $428 \pm 18 \mathrm{~h}$ (mean \pm standard deviation, $\mathrm{N}=10$ ) compared to $508 \pm 45 \mathrm{~h}($ mean \pm standard deviation, $\mathrm{N}=2)$ for the primary control without recirculation. Inspection of Fig 3 might suggest that the duration of the runs with recirculation and feed into the loop was a little shorter than the secondary control; but the standard deviation on the different runs suggests that any difference is within the scatter of the data. Further insight is difficult because culture duration refers to the time when cell viability fell below $30 \%$, a value often reached between samples which were taken every $24 \mathrm{~h}$. Certainly, there is not any indication that with increasing potential stress (increased residence time in the loop or increasing $\mathrm{pH}$ of the addition), a particular trend in the results is indicted. Given the similarity of the results, Fig 4 compares the two control runs without recirculation, with the 10 runs with circulation pooled together. As can be seen, the error bars on the two control runs are similar to those on all the runs with recirculation.

Fig 5 compares the IgG antibody titre using the data for each of the two secondary control runs without recirculation with the data from all the ten runs with continuous recirculation through the PFR whether addition was made into the STR or the PFR. As can be seen, the mean results are very different and the error bars are very small for both data sets. Table 2 also summarises the maximum antibody production rate per cell and the overall titre for all the different runs. It again indicates that though there is a fall in maximum antibody production rate per cell and overall titre of $\sim 25 \%$ and $\sim 20 \%$ respectively with recirculation, it is not possible to detect a trend with increasing stress from additions in the loop. 
On the other hand, in spite of the changes in process performance as a result of recirculation through the loop, the protein quality (mass and charge heterogeneity and glycosolation pattern) was essentially the same for all cases with or without recirculation. For example, Table 3 compares the isoelectric point band values (Ip) from the isoelectric focusing analysis of purified antibody at harvest from the different experimental scale-down conditions and a comparison of the mean values with that of the secondary (PFR) scale down $(\Delta \mathrm{Ip}$ control). Charge heterogeneity is primarily introduced by deamidation and C-terminal lysine micro-heterogeneity (Tsai et al., 1993; Perkins et al., 2000). However, the antibody studied here was missing a C-terminal lysine. Therefore, any change in charge has to be attributed to deamidation, which introduces an additional negative charge to the antibody and generates acidic species, decreasing the protein's isoelectric point (Liu et al., 2008). These factors have been found sensitive to process condition (Jenkins, 2007) and the isoelectric point might reasonably be expected to have fallen after repeated exposure to elevated osmolality and $\mathrm{pH}$ during alkali addition to the PFR. Yet, the variation in mean isoelectric point across the various experimental conditions in Table 3 is insignificant, the difference between the mean Ip of each run and the control mean (here called $\Delta \mathrm{Ip}$ control) being within the expected error range for the technique as experienced at MedImmune.

Another example is shown in Fig 6 where the glycoform patterns are compared. Consistency of glycoform is a major consideration when assessing protein quality for therapeutic purposes (Jenkins, 2007; Godoy-Silva et al., 2009a; 2009b). As can be seen, the small variation in glycoforms between the differing experimental conditions to which the cells were exposed is quite random and typical of that found in industrial historical data. The same conclusion could be drawn from the other assessments of protein quality (data not shown), namely that there was not any significant difference in antibody quality between all the conditions investigated. 
Thus, though this scale-down technique has provided much insight with bacteria, unfortunately, it was not possible to conclude anything concerning the impact of bioreactor heterogeneities with this cell line. It appears that with these $\mathrm{CHO}$ cells, the use of the peristaltic pump itself induced the changes in growth and productivity; but did not impact on product quality.

\subsection{Impact of fluid dynamic stresses}

Two Genentech cell lines were used, one of which (Cell A) was less robust than the other (Cell B), based on their exposure to a single passage through the laminar extensional flow device at $\varepsilon_{L}$ values of $1.1 \times 10^{8} \mathrm{~W} \mathrm{~m}^{-3}$ which had previously been shown to be lethal to cells (Mollet et al., 2007). In all cases, when recirculation was used, it was only begun on day 4 to check that cells were growing within the parameters expected from historical data.

3.2.1 Recirculation with the peristaltic pump.

Primary control and secondary control runs were initially conducted as described above before runs with the device in place were then undertaken. Figure 7 a shows the results for cell growth and titre (normalized for commercial confidentiality) for the more robust cell B for the primary control and secondary control. As can be clearly seen,the data for secondary control without the device (when there should not have been any increased stress) indicates a much lower maximum viable cell count, \% viability and titre. In addition, the results with the runs with the different devices in place were very inconsistent (data not shown). At this time, the problems associated with recirculation by peristaltic pump discussed above in the other experimental study were becoming clear. However, interestingly, as in the above study, the protein quality (assessed using the same experimental criteria as discussed below when using the syringe pump) (data not shown)) were statistically the same for all the runs with the peristaltic pump. 
Overall, it was decided to try circulation with a syringe pump as was used in the previous work by Godoy-Silva et al., (2009a; 2009b) when using the extensional flow device. All further runs related to mechanical stress were undertaken this way.

\subsubsection{Recirculation with the syringe pump.}

These experiments were conducted in the same way as those with the peristaltic pump. However, in this case, the growth curves with the primary and secondary control were very similar (see Fig $7 \mathrm{~b}$ for cell B). In addition, whether the 227 or $762 \mu \mathrm{m}$ device was used giving $\varepsilon_{L}$ values of $2.9 \times 10^{5} \mathrm{~W} / \mathrm{m}^{3}$ and $1.9 \times 10^{3} \mathrm{~W} / \mathrm{m}^{3}$ respectively, the performance with respect to growth and titre was the same as the two controls for both cell lines. Figure 8 shows the results for the more robust cell B at $2.9 \times 10^{5} \mathrm{~W} / \mathrm{m}^{3}$. Essentially, the equivalent results were found for each extensional flow device with each cell line (data not shown).

\subsubsection{Agitation with dual Rushton turbines.}

Two runs were undertaken to give mean specific energy dissipation rates, $\bar{\varepsilon}_{T}$ of either $360 \mathrm{~W} / \mathrm{m}^{3}$ or $1000 \mathrm{~W} / \mathrm{m}^{3}$. Assuming, as explained earlier that $\left(\varepsilon_{T}\right)_{\max }=100 \bar{\varepsilon}_{T}$, then when using two impellers, maximum turbulent specific energy in this run was $1.8 \times 10^{4} \mathrm{~W} / \mathrm{m}^{3}$ or $5.0 \times 10^{4} \mathrm{~W} / \mathrm{m}^{3}$. Thus, whilst the mean values were extremely high compared to that normally used commercially for growing cells $\left(\sim 20 \mathrm{~W} / \mathrm{m}^{3}\right)$ (Nienow, 2006), the maximum is still less than that used in the elongational flow device under laminar conditions. However, though there was a difference between cell lines, the growth and productivity in the Rushton turbine studies was overall in the same range with as that found with both of the devices, with small differences between the control runs and those with the Rushton turbines but without a specific trend (data not shown).

\subsubsection{Product quality.}

Representative product quality data are shown in Fig 9 for cell B for all the configurations and different stress levels studied. Fig 9a shows the \% of the different 
glycoforms whilst in Figs $9 \mathrm{~b}$ the percentage of monomeric mAB is shown. The measurement of charge variants quantifies the acidic, main and basic peaks and in Fig 9c, the results for the main peak are shown. As can be clearly seen, the values for each quality characteristic are consistent for each technique (as were the values for the other charge peaks (data not shown)) over the wide range of stresses employed. Though the absolute values were different, the consistency across the various experiments was very similar for cell A (data not shown).

\subsubsection{Implications for Commercial Cell Culture.}

The consistency with which culture performance at these high stress levels gives results similar to each other and to historical data is contrary to those obtained earlier (Godoy-Silva et al., 2009a; 2009b), which suggests cell line specificity. However, the really important point is this: are any cells (or their product quality) likely to be affected by the values of $\left(\varepsilon_{T}\right)_{\max }$ required to operate cell culture bioreactors successfully, recognizing that the levels of $\bar{\varepsilon}_{T}$ used in this work are up to $\sim 50$ times greater than those currently required? Even allowing for the increased cell density that will probably to be achieved in future and therefore requiring a higher $\bar{\varepsilon}_{T}$ to satisfy the increased oxygen demand, there is a considerable margin available before the levels tested here are reached.

\subsubsection{The Suitability of Extensional Flow for Turbulent Stress Studies.}

The impact of turbulent stresses on entities suspended within it is usually assessed by comparing the size of the entity with the Kolmogorov microscale of turbulence, $\lambda_{K}$ at the maximum specific energy dissipation rate in a stirred bioreactor;

$$
\lambda_{K}=\left(\mu^{3} / \rho^{2}\left(\varepsilon_{T}\right)_{\max }\right)^{1 / 4}
$$

where $\mu$ (Pas) is the viscosity and $\rho\left(\mathrm{kg} / \mathrm{m}^{3}\right)$ is the density. If the size of the entity is $<\lambda_{K}$, it should not be damaged. There are difficulties in applying this concept because values of 
$\left(\varepsilon_{T}\right)_{\max }$ are only available for a few impellers and when they are, the range of values obtained by different workers is large. Nevertheless, such approaches have worked well for many single cell biological entities (bacteria, yeast, animal cells (Nienow, 2006; Hewitt and Nienow, 2007)) as well as for drop breakage in liquid-liquid systems. Indeed, for analysis of the latter topic, completely different theories are applied for turbulent and laminar flow; and under laminar flow conditions, drop breakage occurs under some conditions in extensional flow when it would not for shear flow (Leng and Calabrese, 2004). In addition, for a given geometry, the spatial distribution of turbulent specific energy dissipation rate (even if $\left(\varepsilon_{T}\right)_{\max }$ is not known precisely) is independent of reactor scale, as is Equ 1. Therefore, it is recommended that cell-sensitivity to mechanical stress during cultivation is studied in turbulent stirred bench scale bioreactors for scale-up purposes rather than other configurations.

\subsection{An Overall Perspective from Both Studies}

Given the poorer process performance when using the peristaltic pump to recirculate cells in both studies, it is interesting to consider other reports in the literature which might throw some light on the impact of pumping/recirculation on animal cell culture. Perfusion culture has been frequently studied and often involves the use of pumps to recirculate the cells. Pump damage was found to reduce the viability of a variety of animal cell types, including insect (Merten, 2000; Gorenflo et al., 2004), hybridoma (LaPorte et al., 1996) and CHO cells (Kim et al., 2008). Yet, in perfusion culture, the rate of pumping is far lower than here, circulation rates being about 1 to 10 bioreactor volumes/day (Merten, 2000; Kim et al., 2008) compared to $\sim 100$ to $\sim 200$ per day here.

It is also relevant to consider the impact of peristaltic pumps on other biological entities. In studies of the continuous pumping of blood cells for cardiopulmonary bypass operations, peristaltic pumping has been cited as a cause of lysis and cumulative sub-lethal 
damage generally attributed to compression of the tubing as the pump rollers rotate (Sutera, 1977; Watanabe et al., 2006). Using computational fluid dynamics to model a two roller pump, Mulholland et al. (2005) showed a sharp peak in laminar shear stress of almost 1000 $\mathrm{Pa}$ when the rollers are almost closing the tube. Experiments by Born et al. (1992) indicated lethal damage to suspended animal cells during laminar flow at shear stresses $<100 \mathrm{~Pa}$. On the other hand, Jaspe and Hagen (2006) found shear stresses $>10^{4} \mathrm{~Pa}$ were required to denature proteins whilst others (Bee et al., 2009) have concluded that antibodies cannot be damaged by fluid dynamic stresses without additional interfacial effects too. Similar results have been reported on other protiens since at least 1979 (see, for example, Thomas et al. (1979)).

Overall, from the literature, it can be concluded that sub-lethal damage to the $\mathrm{CHO}$ cells cultivated in this work due to their passage through a peristaltic pump is not an unrealistic explanation for the deterioration in process performance found under those conditions. There is also evidence in the literature over many years that fluid dynamic stresses alone should not damage proteins. Such reports support the other generic finding of these two studies. Whether there is sub-lethal damage to the $\mathrm{CHO}$ cells with the peristaltic pumps; or the cells are exposed to very high energy dissipation rates in laminar extensional flows in the loop or turbulent flows in the bioreactor, the IgG antibody quality is unaffected.

\section{CONCLUSIONS}

Two fed-batch studies cultivating $\mathrm{CHO}$ cells have been undertaken. In the first on $\mathrm{pH}$ and nutrient excursions associated with the simulation of poor homogeneity found on scale up, the method employed was not successful. It failed because it required cells to be circulated for the duration of the culture by peristaltic pump, which in each case led to a reduction in culture time and a concomitant fall in product titre compared to the control without recirculation. In the second, cells were subjected to elevated fluid dynamic stresses 
either by recirculating them through a laminar converging flow device or in the turbulent flow generated in a bioreactor agitated by a Rushton turbine. In this case, cell density and product titre were not affected by the stress whatever the type of flow or level imposed. Very importantly, in every case studied, the IgG product quality was the same as the control regardless of the stress imposed.

It is still not possible to explain the reason for the difference between the current findings and those of Godoy-Silva et al. (2009a; 2009b). A possible one is cell line specific behaviour. If that is the case, it is crucial to have a reliable scale down test for the assessment of cell robustness as new cell lines are introduced. Since turbulent flow is the universal condition in large scale animal culture bioreactors and there is a well-established relationship between damage to entities and the Kolmogorov scale of turbulence, independent of scale, it is suggested that sensitivity to fluid dynamic stresses is best studied in turbulent bench scale bioreactors.

\section{ACKNOWLEDGEMENTS}

The authors would like to thank the companies for the support received whilst doing the work and for permission to publish it. 


\section{NOMENCLATURE AND UNITS}

$\varepsilon_{L} \quad$ Laminar specific energy dissipation rate, $\mathrm{W} / \mathrm{m}^{3}$

$\varepsilon_{T} \quad$ Turbulent local specific energy dissipation rate, $\mathrm{W} / \mathrm{m}^{3}$

$\left(\varepsilon_{T}\right)_{\max }$ Maximum turbulent local specific energy dissipation rate, $\mathrm{W} / \mathrm{m}^{3}$.

$\bar{\varepsilon}_{T} \quad$ Mean turbulent specific energy dissipation rate, $\mathrm{W} / \mathrm{m}^{3}$.

$\lambda_{K} \quad$ Kolmogorov length scale, $\mathrm{m}$

$\mu \quad$ Dynamic viscosity, $\mathrm{Pa} \mathrm{s}$

$\rho \quad$ Density, $\mathrm{kg} / \mathrm{m}^{3}$

$\tau_{R} \quad$ Mean residence time in the loop 


\section{REFERENCES}

Amanullah, A., McFarlane, C.M., Emery, A.N., Nienow; A.W., 2001. Scale down model to simulate spatial ph variations in large scale bioreactors. Biotechnol. Bioeng., 73, 390-399.

Bee, J.S., Stevenson, J.L., Mehta, B., Svitel, J., Pollastrini, J., Platz, R., et al., 2009. Response of a concentrated monoclonal antibody formulation to high shear, Biotechnol. Bioeng., 103, 936- 943.

Chaderjian, W.B., Chin, E.T., Harris, R.T., Etcheverry, T.M., 2005. Effect of copper sulfate on performance of a serum-free $\mathrm{CHO}$ cell culture process and the level of free thiol in the recombinant antibody expressed. Biotechnol. Prog., 21, 550-553.

Godoy-Silva, R., Mollet, M., Chalmers, J.J., 2009a. Evaluation of the effect of chronic hydrodynamical stresses on cultures of suspended cho-6e6 cells. Biotechnol. Bioeng. 102, 1109-1130.

Godoy-Silva, R, Chalmers, J.J., Casnocha, S.A., Bass, L.A., Ma, N., 2009b. Physiological responses of cho cells to repetitive hydrodynamic stress. Biotechnol. Bioeng. 103, 11031117.

Gorenflo, V.M., Pfeifer, T.A., Lesnicki, G., Kwanm E.M., Grigliatti, T.A., Kilburn, D.G. et al., 2004. Production of a self-activating cbm-factor $\mathrm{x}$ fusion protein in a stable transformed Sf9 insect cell line using high cell density perfusion culture. Cytotechnology, 44, 93-102.

Guile, G.R., Rudd, P.M., Wing, D.R., Prime, S.B., Dwek, R.A., 1996. A rapid highresolution high-performance liquid chromatographic method for separating glycan mixtures and analyzing oligosaccharide profiles. Analytical Biochemistry. 240, 210-226.

Hewitt, C.J., Nienow, A.W., 2007. The scale-up of microbial batch and fed-batch fermentation processes. Adv. in App. Microbiol., 62, 105-136.

Jaspe, J., Hagen, S.J., 2006. Do protein molecules unfold in simple shear flow? Biophys. J. 91, 3415-3424.

Jenkins N., 2007.. Modification of therapeutic proteins: challenges and prospects. Cytotechnology. 53, 121-125.

Kim, B.J., Oh, D.J,, Chang, H.N.. 2008. Limited use of centritech lab ii centrifuge in perfusion culture of rcho cells for the production of recombinant antibody. Biotechnol. Prog. 24, 166-174.

Langheinrich, C., Nienow, A.W., 1999. Control of $\mathrm{pH}$ in large scale, free suspension animal cell bioreactors: alkali addition and pH excursions, Biotechnol. Bioeng. 66, 171-179. 
LaPorte, T.L., Shevitz, J., Kim, Y., Wang, S.S., 1996. Long term shear effects on a hybridoma cell line by dynamic perfusion devices. Bioproc. Biosys. Eng. 15, 1-7.

Larsson, G., Enfors, S.-O., 1988. Studies of insufficient mixing in bioreactors-effects of limiting oxygen concentrations and short-term oxygen starvation on Penicillium chrysogenum. Bioprocess. Eng., 3, 123-127.

Leng D.E., Calabrese R.V., 2004. Immiscible liquid-liquid systems, in: Paul, E.L., AtiemoObeng, V.A., Kresta, S.M. (Eds), Handbook of Industrial Mixing. Science and Practice, John Wiley \& Sons Inc., Hoboken, New Jersey, pp. 689-753.

Liu, H., Gaza-Bulseco, G., Faldu, D., Chumsae, C., Sun, J. 2008. Heterogeneity of Monoclonal Antibodies. J. Pharm. Sci. 97, 2426-2447.

Merten, O.W., 2000. Constructive improvement of the ultrasonic separation device ADI 1015. Cytotechnology, 34, 175-179.

Mollet, M., Godoy-Silva, R., Berdugo, C., Chalmers, J.J. 2007. Acute hydrodynamic forces and apoptosis: A complex question. Biotechnol. Bioeng. 98, 772-788.

Mulholland, J.W., Shelton, J.C., Luo, X.Y., 2005. Blood flow and damage by the roller pumps during cardiopulmonary bypass. J. Fluids Struct. 20, 129-140.

Namdev, K.P., Thompson, B.G., 1992. Effect of feed zone in fed-batch fermentations of Saccharomyces cerevisiae. Biotechnol. Bioeng. 40, 235-246.

Nienow, A.W., 2006. Reactor engineering in large scale animal cell culture. Cytotechnology, 50, 9-33.

Osman, J.J., Birch, J., Varley, J., 2002. The response of GS-NSO myeloma cells to single and multiple pH perturbations, Biotechnol. Bioeng. 79, 398-407.

Perkins, M., Theiler, R., Lunte, S., Jeschke, M., 2000. Determination of the origin of charge heterogeneity in a murine monoclonal antibody. Pharma. Res. 17, 1110-1117.

Pullen, K.F., Johnson, M.D., Phillips, A.W., Ball, G.D., Finter, N.B., 1985. Very large-scale suspension cultures of mammalian cells. Dev. Biol. Std., 60, 175-185.

Scott, W.H., 2011. Impact of environmental heterogeneities during fed-batch GS-CHO cell culture. $\mathrm{PhD}$ thesis, University of Birmingham, UK.

Sutera, S.P., 1977. Flow-induced trauma to blood cells. Circulation Res. 41. 2-8.

Telling, R.C., Elsworth, R., 1965. Submerged culture of hamster kidney cells in a stainless steel vessel. Biotechnol. Bioeng. 7, 417-434.

Tsai, P,K., Bruner, M.W., Irwin, J.I., Ip, C.C.Y., Oliver, C.N., Nelson, R.W. et al.. 1993. Origin of the isoelectric heterogeneity of monoclonal immunoglobulin H1B4. Pharma. Res. $10,1580-1586$. 
Watanabe, N., Kataoka, H., Yasuda, T., Takatani. S., 2006. Dynamic deformation and recovery response of red blood cells to a cyclically reversing shear flow: effects of frequency of cyclically reversing shear flow and shear stress level. Biophys. J. 91, 1984-1998.

Zhang, Z., Pan, H., Chen, X., 2009. Mass spectrometry for structural characterisation of therapeutic antibodies. Mass Spectrometry Revs. 28, 147-176. 


\section{Figures}

Figure 1: Schematic of the secondary control experiment with a plug flow reactor (PFR) and of scale-down test runs where recirculation by peristaltic pump was continuous for both cases. In the secondary control, additions are made only to the stirred tank reactor (STR). In the scale-down runs, additions were made to the PFR as described in Table 1.

Figure 2 Growth curves for the fed-batch primary control for the homogeneity study: Comparison of flow cytometer (FC) and haemocytometer data (HC) (viable cell number $(\mathrm{VCN})($ cells $/ \mathrm{mL})$, dead cell number $(\mathrm{DCN})($ cells $/ \mathrm{mL})$ and viability $(\%))$. (Each point is the average of duplicate experiments; error bars represent the data range).

Figure 3 Growth curves from all runs with recirculation based on haemocytometer data; Open symbols for secondary control (addition into the stirred bioreactor), closed for scale down simulations by addition into PFR (the same secondary control data are shown in each figure); (viable cell number (cells/mL), squares; dead cell number (cells $/ \mathrm{mL}$ ), triangles; viability (\%), circles): a) $\mathrm{pH}$ chemicals addition, mean residence time, $\tau_{R}=60 \mathrm{~s}$; b) $\mathrm{pH}$ chemicals and glucose supplement addition, $\tau_{R}=60 \mathrm{~s}$; c) $\mathrm{pH}$ chemicals and glucose supplement,addition, $\tau_{R}=120 \mathrm{~s} ; \mathrm{d}$ ) $\mathrm{pH}$ chemicals (x 100 concentration) and glucose supplement,addition, $\tau_{R}=120 \mathrm{~s}$.

Figure 4 Comparison of growth curves from primary control experiments without continuous recirculation (closed) with all those with continuous recirculation (open) based on haemocytometer data: (viable cell number (cells/mL), squares; dead cell number (cells $/ \mathrm{mL}$ ), triangles; viability (\%), circles). Each point is the mean and error bars are 1 standard deviation. (Experiments with recirculation, $\mathrm{N}=10$; without recirculation, $\mathrm{N}=2$ ).

Figure 5 IgG antibody titre for runs with (open points) and without (closed points) continuous recirculation through the PFR. (Each time point is the mean and error bars are 1 standard deviation: tests with recirculation, $\mathrm{N}=10$, tests without, $\mathrm{N}=2$ ).

Figure 6 Mean relative \% of each glycoform on the IgG antibody for each pair of duplicate experiments at the end of the fed-batch process: primary control (dots); secondary control 
(black); pH, $60 \mathrm{~s}$ (narrow forward slash); $\mathrm{pH}$ and substrate, $60 \mathrm{~s}$ (wide forward slash); $\mathrm{pH}$ and substrate, $120 \mathrm{~s}$ (narrow back slash); $\mathrm{pH}$ (x100) and substrate, $120 \mathrm{~s}$ (wide back slash).

Figure 7 Growth curves for the lower sensitivity cell B: a) Primary control (open symbols, $\mathrm{n}=7$ ) and secondary control with recirculation by peristaltic pump (closed symbols, $\mathrm{n}=3$ ); b) Primary control (open symbols, $\mathrm{n}=7$ ) and secondary control with recirculation by syringe pump (closed symbols, $n=7$ ).. (Squares, viability; diamonds, viable cells; triangles, titre; the error bars indicate one standard deviation, dashed line at day 4 indicates when recirculation). was started

Figure 8 Cell B: Recirculation from day 4 (indicated by dotted line) by syringe pump without the device (secondary control-open symbols, $\mathrm{n}=2$ ) and with $272 \mu \mathrm{m}$ device (closed symbols, $\mathrm{n}=2$ ) to give $\varepsilon_{L}$ of $2.9 \times 10^{5} \mathrm{~W} / \mathrm{m}^{3}$. (Squares, viability; diamonds, viable cells; triangles, titre; the error bars indicate one standard deviation).

Figure 9 Cell B: Product quality for all the different operating conditions with recirculation using the syringe pump and the elongational flow device; and with the Rushton turbines: a) glycoform profiles; b) mAb \% monomer; and c) charge variant ( $\%$ main peak). 


\section{Tables}

Table 1 Description of experimental protocol for the inhomogeneity study.

Table 2 Growth and productivity data for each condition studied: maximum specific growth rate $\left(\mu_{\max }\right)$, maximum viable cell number $\left(\mathrm{VCN}_{\max }\right)$, maximum specific rate of antibody productivity ( $\mathrm{q} \operatorname{IgG}_{\max }$ ); harvest antibody titre (IgG titre) (In this Table, '60s' and ' $120 \mathrm{~s}$ ' refer to the residence time of the recirculated medium and cells in the PFR; and 'sub' and ' $\mathrm{pH}$ ' refer to the glucose supplement and $\mathrm{pH}$ chemicals respectively that were added into the PFR).

Table 3 The six isoelectric point band values and their mean from a scan of the gel plate (not shown) produced during isoelectric focusing analysis of samples of purified antibody at harvest from each of the two control experiments and of the four simulated scale-down experimental conditions; and the means (mean Ip) are compared with the secondary control experiment $(\Delta \mathrm{Ip}$ control $=\mathrm{Ip}$ for the particular run minus Ip for the secondary control $)$.

\section{Tables}

Experiments Simulating a $20 \mathrm{~m}^{3}$ Bioreactor Each run done in duplicate

- Control 1; No recirculation, Fed batch STR without PFR

$\tau_{R}=60 \mathrm{~s}$

- Control 2; Recirculation through STR + PFR feeding alkali and substrate into STR

- Recirculation through STR + PFR with substrate fed to the STR and alkali (pH 9.7) to the PFR (三 surface feed)

- Recirculation through STR + PFR with substrate and alkali fed to the PFR (三 surface feed for both)

$\tau_{R}=120 \mathrm{~s}$

- Recirculation through STR + PFR with substrate and alkali fed to the PFR (三 surface feed for both)

- Recirculation through STR + PFR with substrate and alkali (x 100 higher concentration, pH 12.3) fed to the PFR (三 surface feed for both) 
( $\tau_{R}$ fixed by flow rate from the peristaltic pump)

Table 1 


\begin{tabular}{lllll}
\hline Experimental Case & $\boldsymbol{\mu}_{\text {max }}$ & $\mathbf{V C N}_{\text {max }}$ & $\mathbf{q I g G}_{\max }$ & Titre \\
& $\left.\mathbf{( h}^{-\mathbf{1}}\right)$ & $\mathbf{1 0}$ cells/mL & $\mathbf{p g} / \mathbf{c e l l} / \mathbf{h}$ & $\mathbf{m g} / \mathbf{L}$ \\
\hline Primary control fed-batch STR & 0.026 & 78 & 1.48 & 1003 \\
Primary control fed-batch STR & 0.025 & 89 & 1.65 & 1031 \\
Secondary control (PFR in place) & 0.027 & 86 & 1.04 & 786 \\
Secondary control (PFR in place) & 0.037 & 84 & 1.18 & 811 \\
pH (60 s) & 0.026 & 94 & 1.14 & 776 \\
pH (60 s) & 0.031 & 81 & 1.44 & 752 \\
pH \& sub (60 s) & 0.028 & 75 & 1.02 & 791 \\
pH \& sub (60 s) & 0.033 & 77 & 0.97 & 729 \\
pH \& sub (120 s) & 0.027 & 82 & 1.26 & 804 \\
pH \& sub 120 s) & 0.033 & 82 & 1.26 & 784 \\
pH (100x) \& sub (120 s) & 0.030 & 80 & 1.29 & 841 \\
pH (100x) \& sub (120 s) & 0.028 & 80 & 1.31 & 819 \\
\hline
\end{tabular}

Table 2 


\section{Control \\ (PFR)}

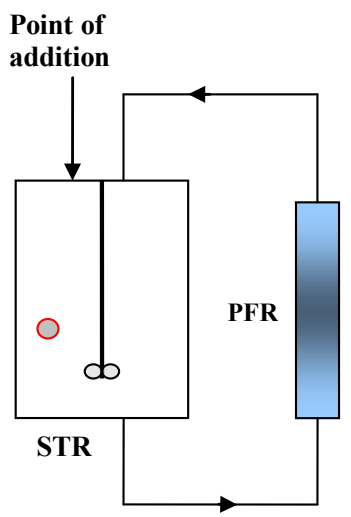

Scale-Down

(Test Runs)

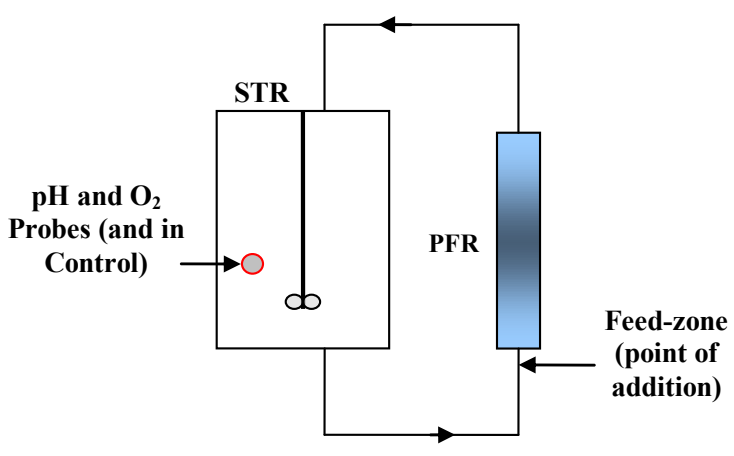

Experim.Primary Secondary $\mathrm{pH}, \mathrm{pH}$

\& $\mathrm{pH} \&$ substrate, $\mathrm{pH} \quad(\mathrm{x} \quad 100) \quad \&$ ent control. Cont. 60s. substrate, 60s. 120s. substrate, 120s

\begin{tabular}{lllllll}
\hline & 6.72 & 6.70 & 6.66 & 6.61 & 6.63 & 6.61 \\
& 6.60 & 6.57 & 6.54 & 6.49 & 6.49 & 6.48 \\
& 6.50 & 6.47 & 6.45 & 6.42 & 6.41 & 6.40 \\
& 6.46 & 6.43 & 6.40 & 6.36 & 6.36 & 6.35 \\
& 6.42 & 6.38 & 6.36 & 6.34 & 6.30 & 6.29 \\
& 6.37 & 6.32 & 6.30 & 6.26 & 6.24 & 6.23 \\
\hline Mean Ip 6.51 & 6.48 & 6.45 & 6.41 & 6.41 & 6.39 \\
$\begin{array}{l}\text { CIp } \\
\text { Control }\end{array}$ & 0.03 & & & & & \\
\hline
\end{tabular}

Table 3

Figures 
Figure 2 
Error!

codes.

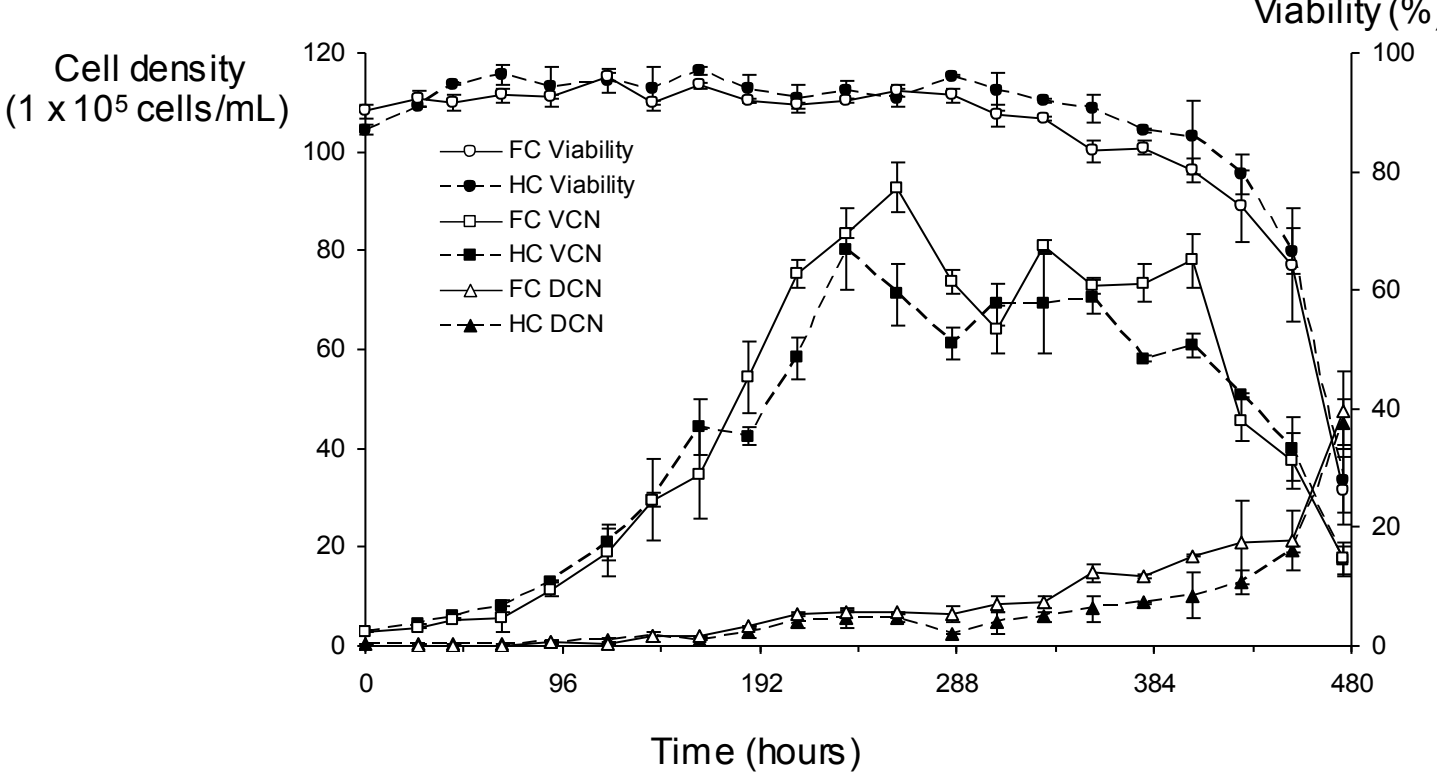

Figure 2 
Error! Objects cannot be created from editing field codes.

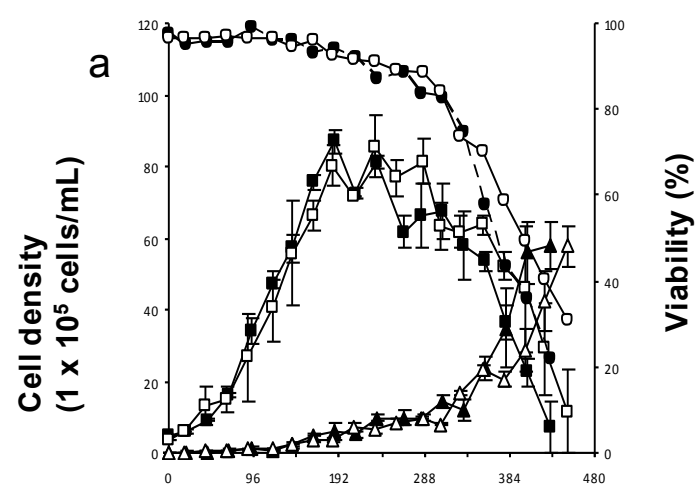

Time (hours)

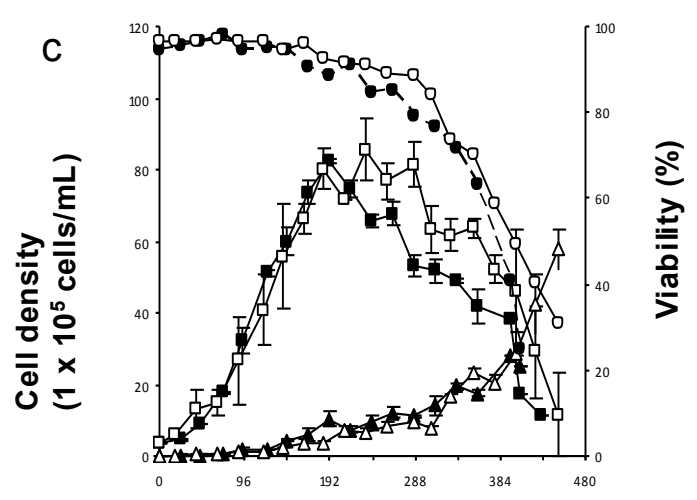

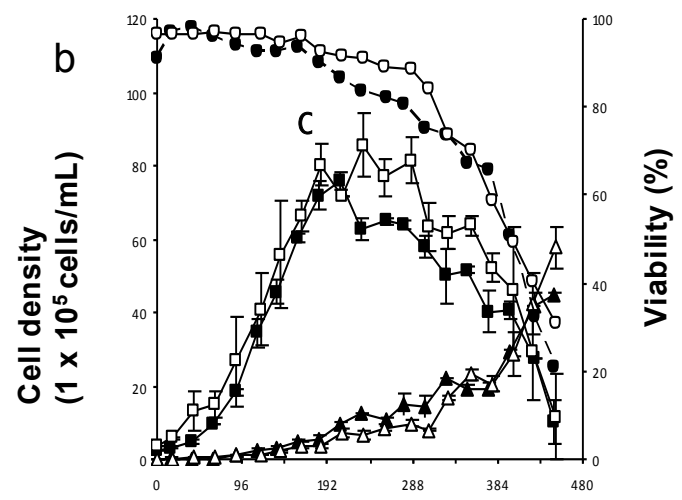

Time (hours)

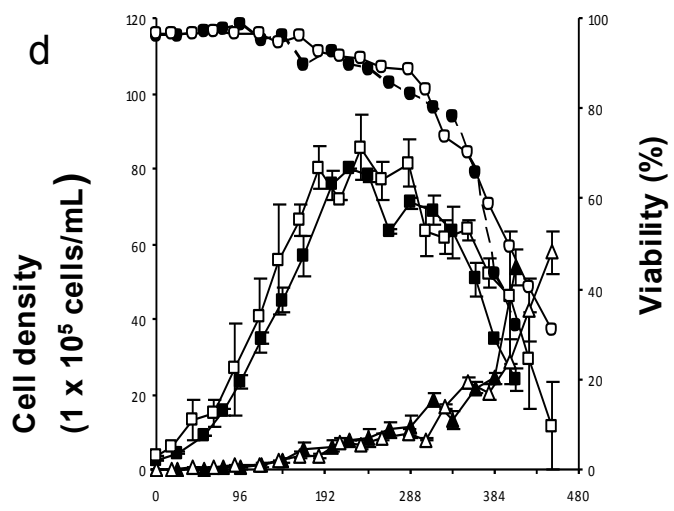

Figure 3 


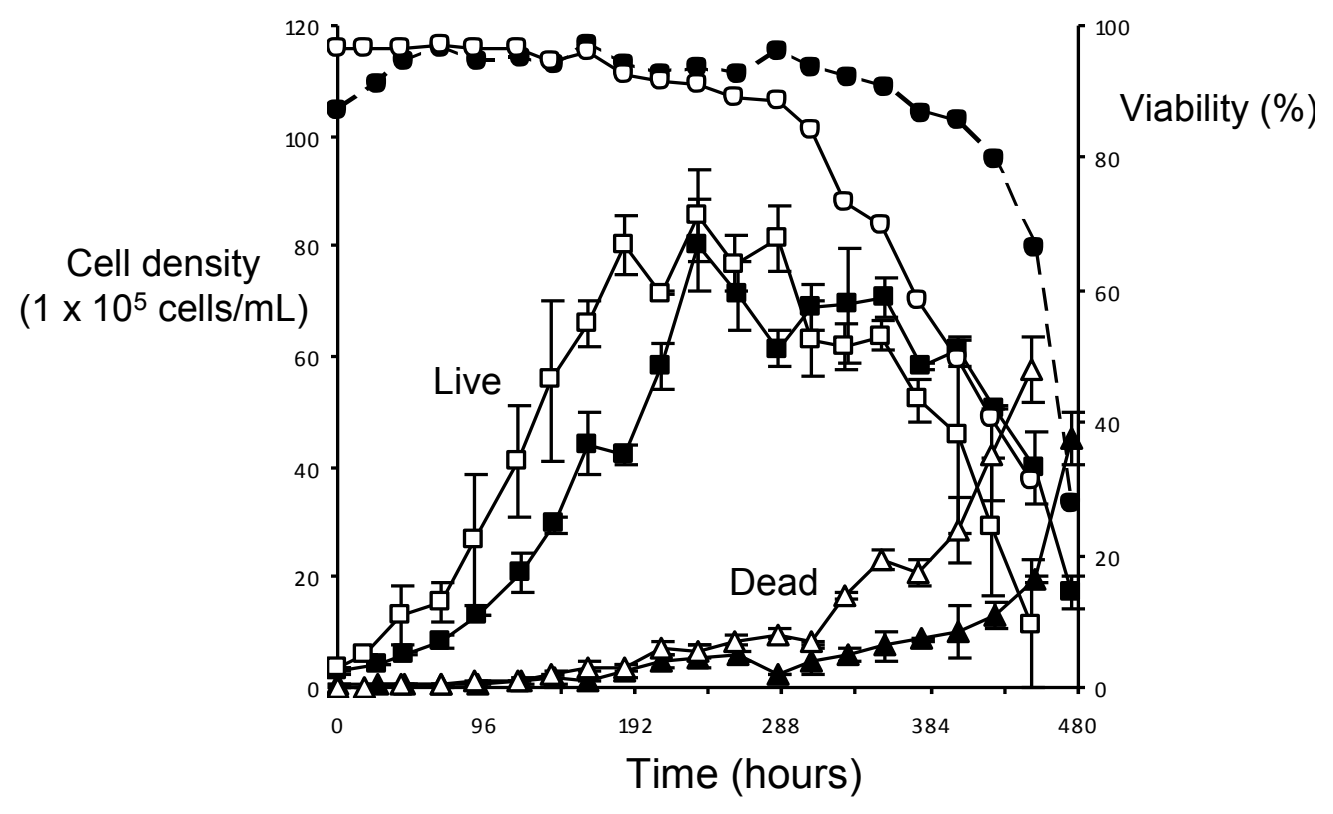

Figure 4 
Error! Objects cannot be created from editing field

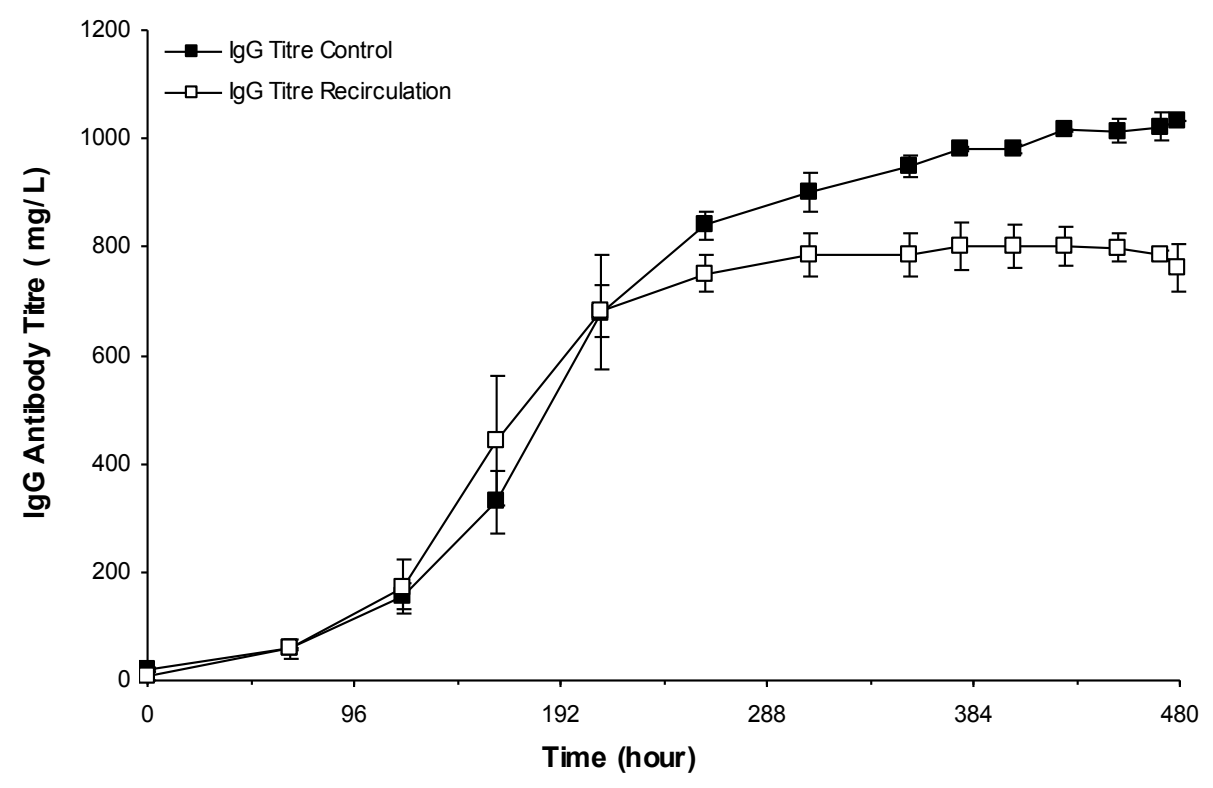

codes.

Figure 5 


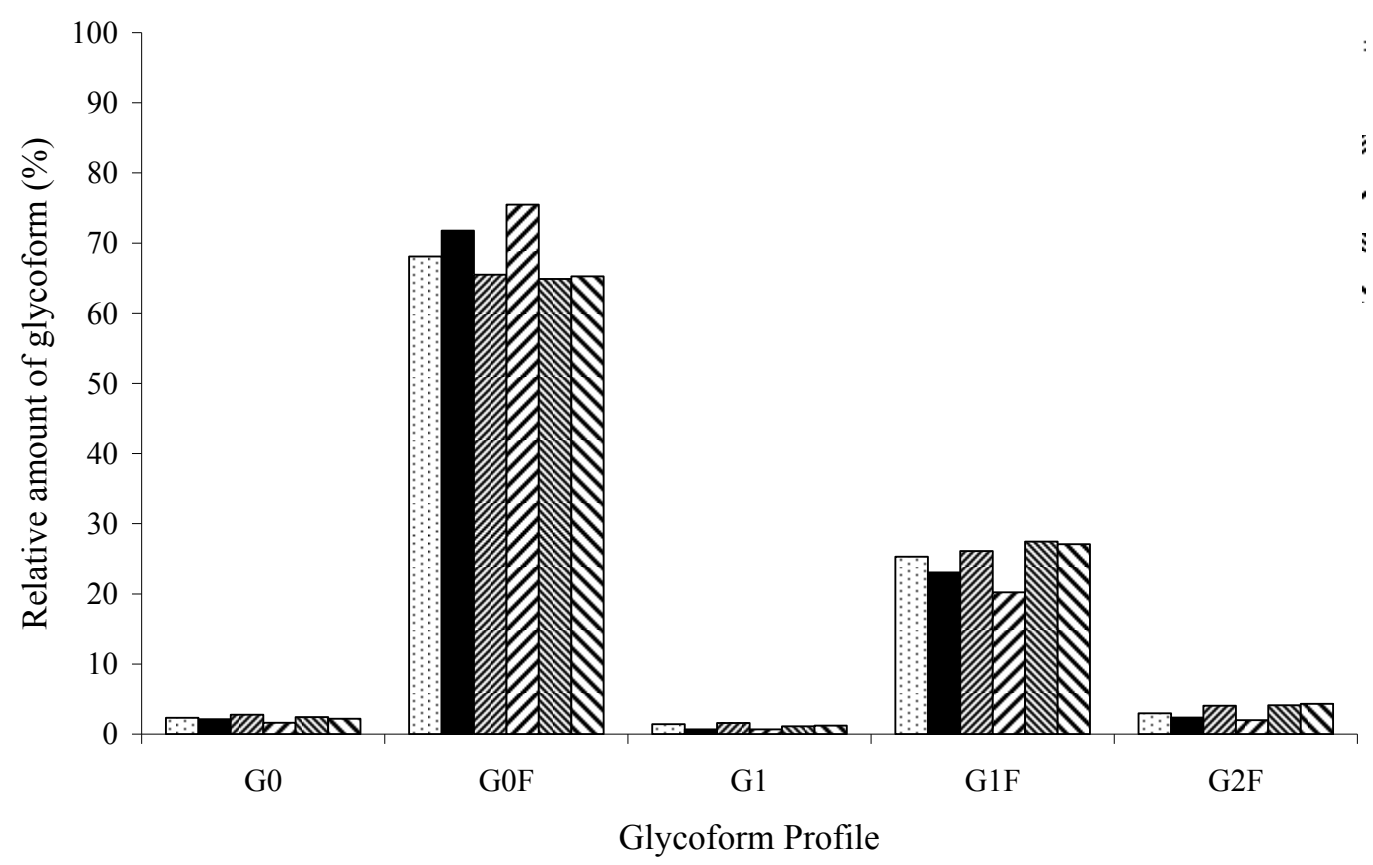

Figure 6 


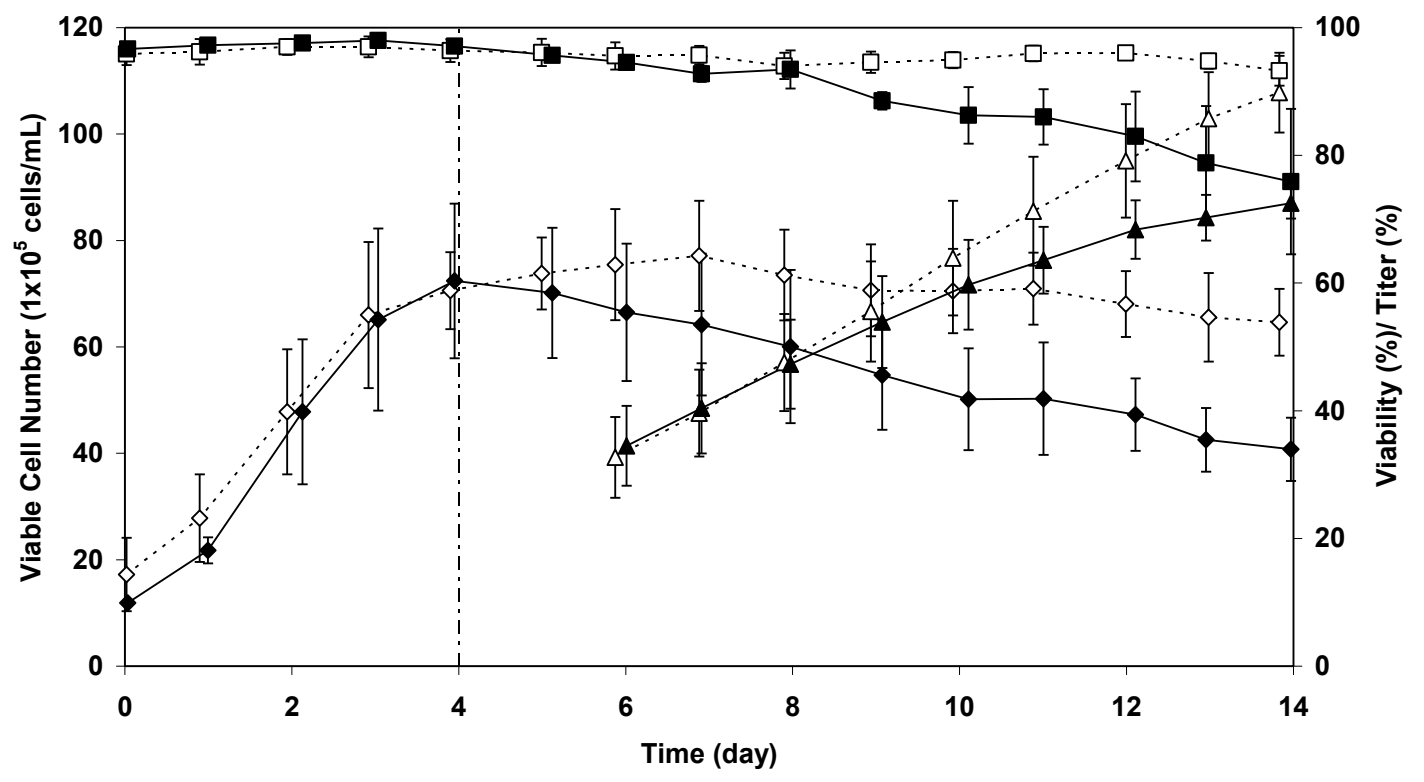

a) 


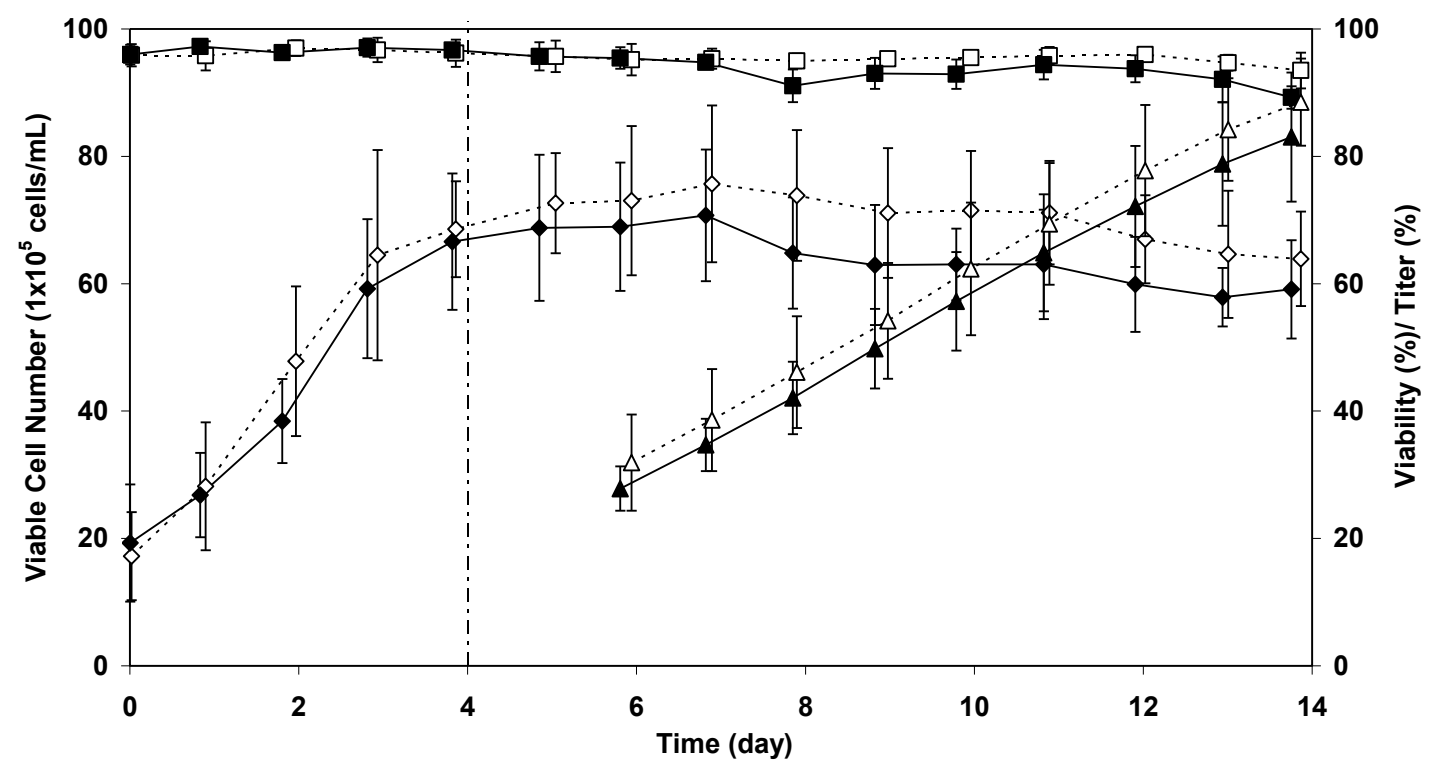

b)

Figure 7 


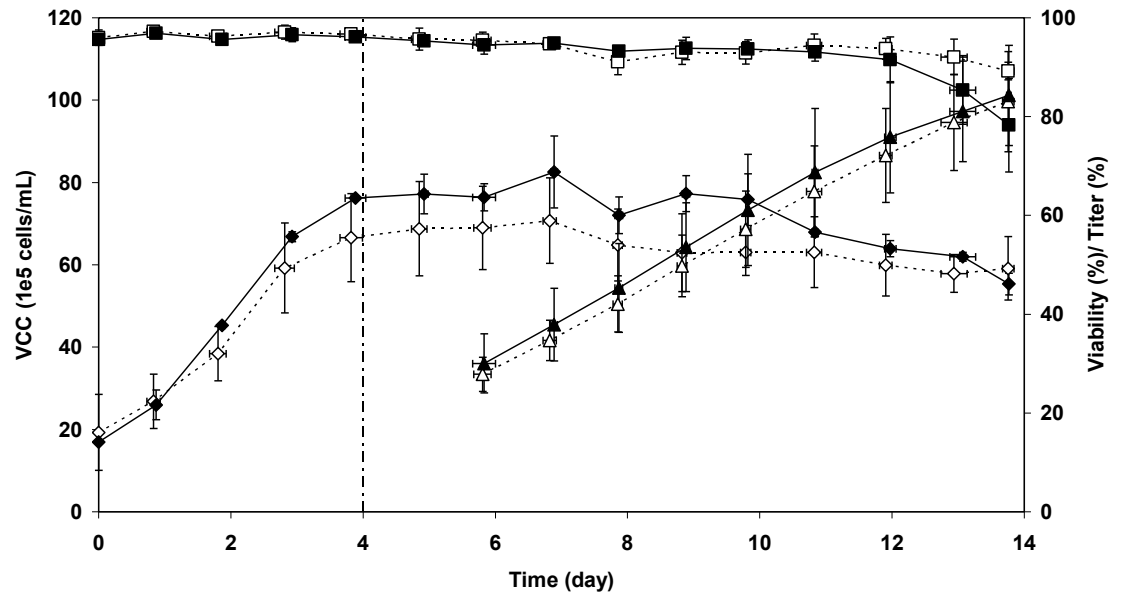

Figure 8 
Error! Objects cannot be created from editing field

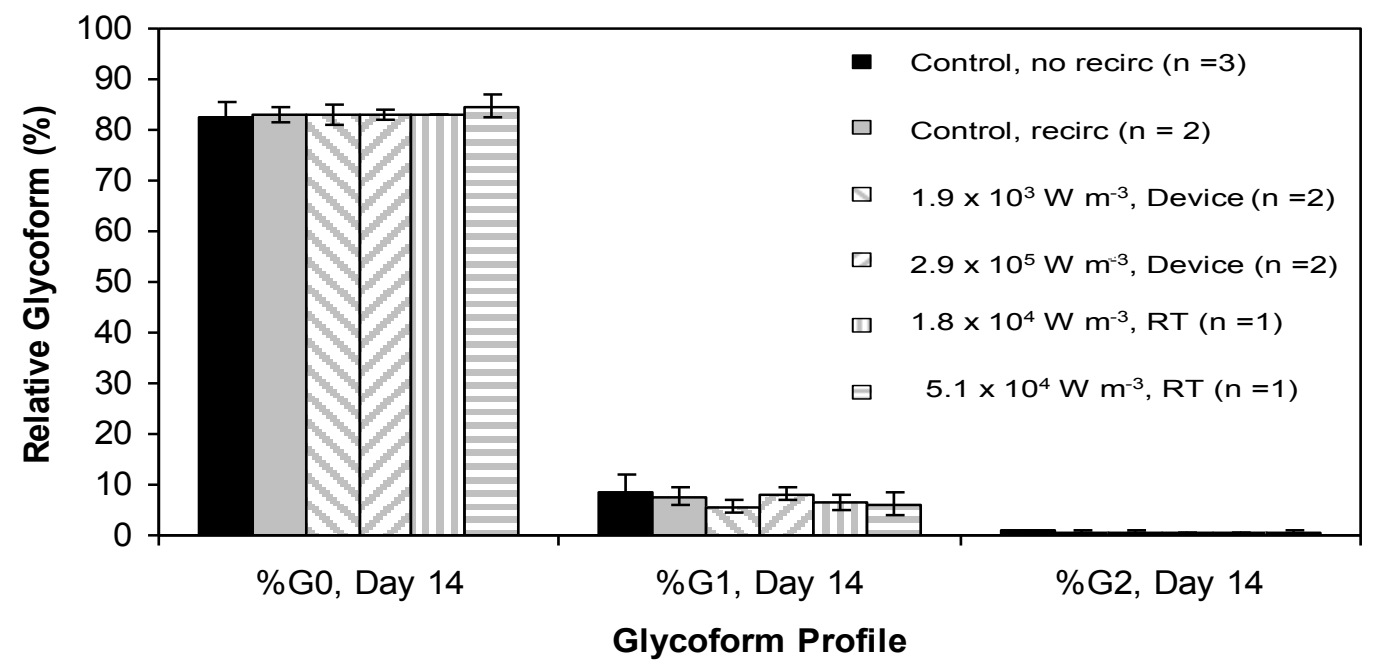

codes.

Figure 9a 
Error! Objects cannot be created from editing field

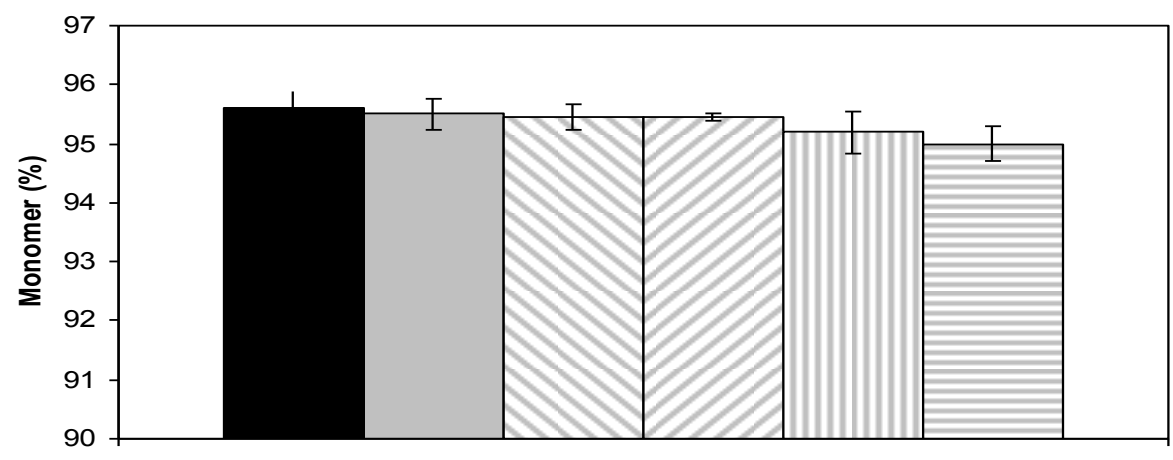

Monomer, Day 14

codes.

Figure $9 b$ 
Error! Objects cannot be created from editing field

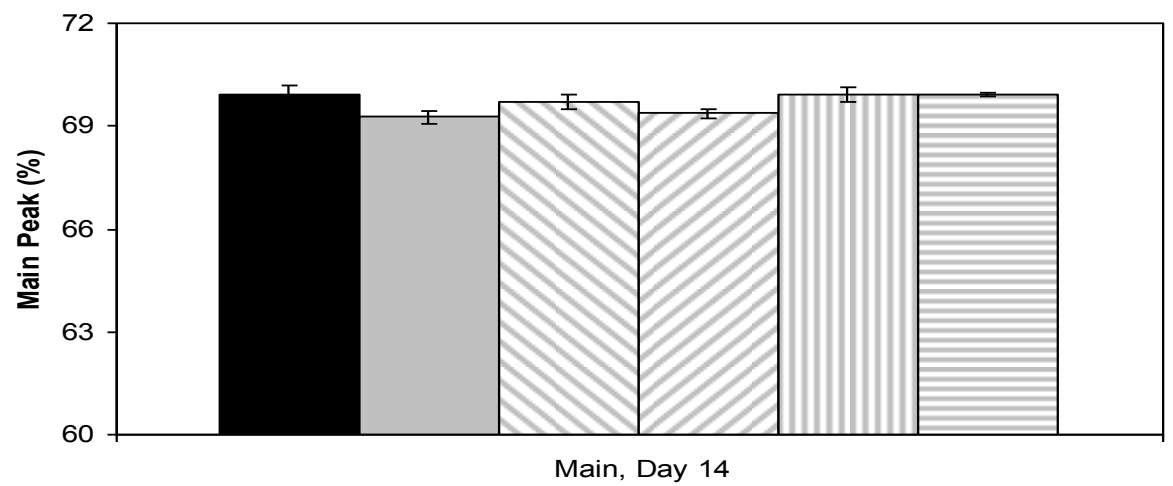

codes.

Figure 9c 
